\title{
T-Cell Tolerance: Central and Peripheral
}

\author{
Yan Xing and Kristin A. Hogquist \\ Center for Immunology, Department of Laboratory Medicine and Pathology, University of Minnesota, \\ Minneapolis, Minnesota 55455 \\ Correspondence: hogqu001@umn.edu
}

Somatic recombination of TCR genes in immature thymocytes results in some cells with useful TCR specificities, but also many with useless or potentially self-reactive specificities. Thus thymic selection mechanisms operate to shape the T-cell repertoire. Thymocytes that have a TCR with low affinity for self-peptide-MHC complexes are positively selected to further differentiate and function in adaptive immunity, whereas useless ones die by neglect. Clonal deletion and clonal diversion (Treg differentiation) are the major processes in the thymus that eliminate or control self-reactive T cells. Although these processes are thought to be efficient, they fail to control self-reactivity in all circumstances. Thus, peripheral tolerance processes exist wherein self-reactive T cells become functionally unresponsive (anergy) or are deleted after encountering self-antigens outside of the thymus. Recent advances in mechanistic studies of central and peripheral T-cell tolerance are promoting the development of therapeutic strategies to treat autoimmune disease and cancer and improve transplantation outcome.

$\mathrm{T}$ cells recognize pathogen fragments in the context of surface MHC molecules on host cells. As such, they have the potential to do enormous damage to healthy tissue when they are not appropriately directed, that is, when they respond to self-antigens as opposed to foreign antigens. T lymphocyte tolerance is particularly important, because it impacts B-cell tolerance as well, through the requirement of $\mathrm{T}$ cell help in antibody responses. Thus, failure of T-cell tolerance can lead to many different autoimmune diseases. The tolerance of $\mathrm{T}$ cells begins as soon as a T-cell receptor is formed and expressed on the cell surface of a T-cell progenitor in the thymus. Tolerance mechanisms that operate in the thymus before the maturation and circulation of T cells are referred to as "central tolerance."
However, not all antigens that $\mathrm{T}$ cells need to be tolerant of are expressed in the thymus, and thus central tolerance mechanisms alone are insufficient. Fortunately, additional tolerance mechanisms exist that restrain the numbers and or function of $\mathrm{T}$ cells that are reactive to developmental or food antigens, which are not thymically expressed. These mechanisms act on mature circulating $\mathrm{T}$ cells and are referred to as "peripheral tolerance."

\section{CENTRAL TOLERANCE}

T lymphocytes arise from circulating bone-marrow-derived progenitors that home to the thymus. After T lineage commitment and expansion, T-cell receptor (TCR) gene rearrangement

Editors: Diane J. Mathis and Alexander Y. Rudensky

Additional Perspectives on Immune Tolerance available at www.cshperspectives.org

Copyright (C) 2012 Cold Spring Harbor Laboratory Press; all rights reserved; doi: 10.1101/cshperspect.a006957

Cite this article as Cold Spring Harb Perspect Biol 2012;4:a006957 
ensues and gives rise to either $\gamma \delta$ or $\alpha \beta$ progenitors at the CD4 and CD8 double-negative (DN) stage. A small number of $\alpha \beta$ committed DN cells give rise to a large number of $\mathrm{CD} 4$ and CD8 double-positive (DP) thymocytes, and somatic recombination of TCR genes results in a remarkably broad repertoire of distinct $\alpha \beta$ TCRs with random specificity. The TCR affinity for self-peptide - major histocompatibility complex (MHC) determines a thymocyte's fate from this point forward (Fig. 1). DP thymocytes expressing TCRs that do not bind self-peptideMHC complexes die by neglect. Those with a low affinity for self-peptide-major histocompatibility complex MHC complexes differentiate to CD4 or CD8 single-positive (SP) thymocytes-so-called positive selection. However, those with high-affinity TCR for self-peptideMHC complexes represent a potential threat to the health of the animal, and various mechanisms operate to ensure tolerance to self, including clonal deletion, clonal diversion, receptor editing, and anergy.

In the thymus, one of the main mechanisms of T-cell tolerance is "clonal deletion," although the selection of regulatory $\mathrm{T}$ cells ("clonal diversion") is also important and is of enormous interest (see Benoist 2012). Thymocytes expressing high-affinity TCR for self-peptide-MHC can avoid the deletion or diversion fates via un- dergoing secondary gene rearrangement at the TCR $\alpha$ loci, thereby changing the specificity of the TCR. This process is known as "receptor editing." Although examples of receptor editing exist for T cells (Wang et al. 1998; McGargill et al. 2000, 2002; Buch et al. 2002; Santori et al. 2002), it is unclear how prominent this mechanism is (Holman et al. 2003), and it will not be discussed further here. Finally, a state of unresponsiveness can be induced in self-reactive thymocytes, called "anergy." Anergy is likely a more prominent tolerance mechanism that operates in the periphery and is discussed further in that section. These four processes-clonal deletion, clonal diversion, receptor editing, and anergy-are the major mechanisms that limit the self-reactivity of the T-cell repertoire and are crucial for immune health.

\section{CLONAL DELETION}

In this section, we discuss several fundamental questions of clonal deletion, such as: At which stages of development do thymocytes undergo deletion? Where does it occur anatomically? What cell types induce apoptosis? What is the molecular mechanism?

The thymus is composed of two major anatomical areas-an outer region known as the cortex, which contains DN and DP thymocytes,

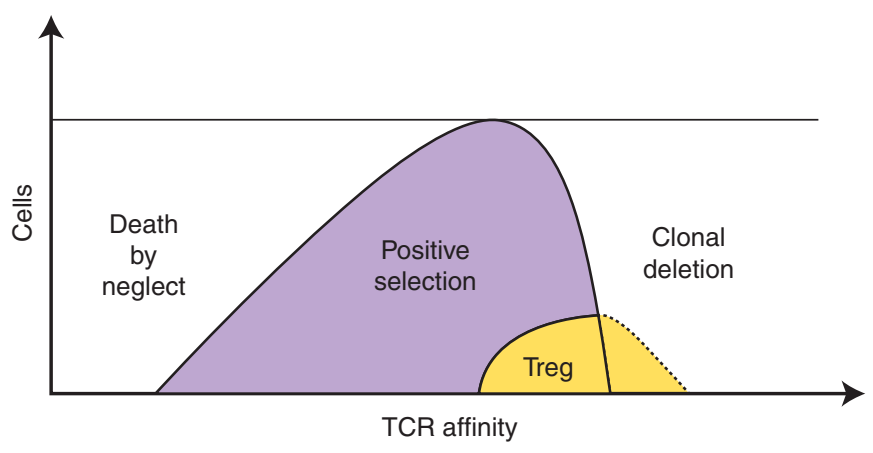

Figure 1. A model for the relationship between developmental outcome and TCR affinity for self-peptideMHC. Cells with TCR that have a low affinity for self die by neglect. Those with an intermediate affinity are positively selected. High-affinity self-reactive clones can die via clonal deletion, and the threshold between positive and negative selection is hypothesized to be steep. Regulatory T cells (Treg) (yellow) have more highly self-reactive TCRs than most conventional T cells (purple). Some Tregs may have very highly self-reactive TCRs and are rescued from deletion via cytokine signaling or by virtue of having a second TCR (dotted line). 
T-Cell Tolerance

and an inner region known as the medulla, which contains SP thymocytes (Fig. 2). Positive selection of thymocytes occurs in the cortex. However, whether or not clonal deletion occurs in the cortex has been controversial. For example, superantigen studies have suggested that deletion occurs at the SP stage (Kappler et al. 1987) (in the thymic medulla), whereas examination of TCR transgenics and endogenous self-antigens had suggested that deletion occurs at the transition from DN to DP (Kisielow et al. 1988; Sha et al. 1988) (in the thymic cortex). This apparent discrepancy can be partially rec- tified by the observation that superantigens are primarily expressed in the medulla, which is the site where SP thymocytes reside. Likewise, tissue-specific antigens are often expressed exclusively in the medulla (see below for further discussion). In contrast, in TCR transgenic models where the TCR is specific for ubiquitous selfantigens, deletion occurs at the DN-to-DP transition. However, in transgenic models, thymocytes express both TCR $\beta$ and TCR $\alpha$ chains early at the DN stage and undergo negative selection prematurely (Baldwin et al. 2005; Egawa et al. 2008). What is clear is that the nature of TCR

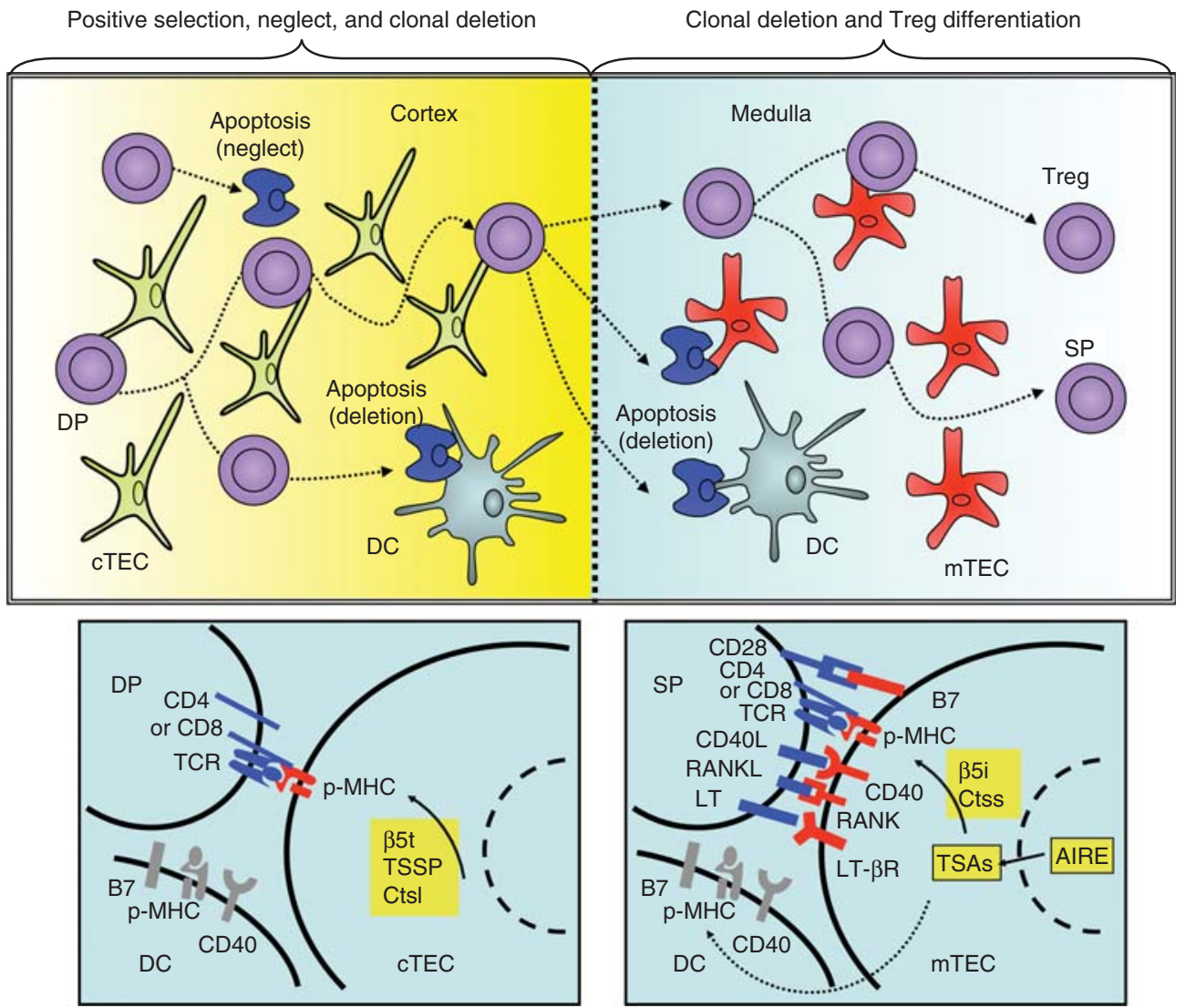

Figure 2. Cell types in central tolerance. (Top) T cells are positively selected in the thymic cortex. Negative selection via clonal deletion can also occur in the cortex, but occurs frequently in the medulla. The thymic medulla is also the site for Treg differentiation. (Bottom) Cortical thymic epithelial cells (cTECs) express several unique genes that relate to proteolysis (cathepsin L, Ctsl; thymus-specific serine protease, TSSP; and $\beta-5 \mathrm{t}$ proteasome subunit, $\beta 5 \mathrm{t}$ ), which are essential for positive selection. Tissue-specific antigens (TSAs) can be directly presented by medullary thymic epithelial cells (mTECs) or cross-presented by DC (dotted line with arrow). RANKL, CD40L, and lymphotoxin (LT) expressed by SP thymocytes interact with their receptors on mTEC to promote the development of mTEC. 
and self-antigen expression can dramatically impact the timing of clonal deletion and the molecular mechanism by which apoptosis is induced (McCaughtry and Hogquist 2008). It is therefore important to move forward making use of the most physiological tools available. Using a TCR transgenic mouse that recapitulates the appropriate timing of TCR $\alpha$ expression at the DP stage, it was shown that deletion of $T$ cells specific for ubiquitous antigens occurs at the DP-to-SP transition (Baldwin et al. 2005). In terms of physical location, this deletion event was shown to occur in the cortex (McCaughtry et al. 2008). Thus, in general, polyclonal thymocytes specific for ubiquitous self-antigens seem to be deleted in the thymic cortex, whereas those restricted to tissue-specific antigens, some superantigens, and circulating antigens all occur in the thymic medulla. The relative proportion of the repertoire specific to each of these types of antigens has not yet been determined.

Multiple aspects of T-cell development in the thymus, including clonal deletion, depend crucially on interactions with other cells in the thymic microenvironment. Although the thymus is composed of predominantly T-cell progenitors, there are small numbers of stromal cells, which include hematopoietic non-T-cell progenitors, such as macrophages and dendritic cells (DCs), and non-hematopoietic cells, such as epithelial cells and fibroblasts. Epithelial cells of the thymic cortex (cTECs) are required for positive selection of thymocytes, whereas medullary thymic epithelial cells (mTECs) and DC are more important for Treg differentiation and clonal deletion (Fig. 2).

\section{THYMIC APCs: mTECs}

mTECs play a crucial role in thymic tolerance. They are unique among thymic antigen-presenting cells (APCs) in that they express a large number of tissue-specific self-antigens (TSAs) (Derbinski et al. 2001; Gotter et al. 2004). They also express an interesting nuclear regulatory protein called autoimmune regulator (AIRE). Mutations in the AIRE gene lead to the multiorgan syndrome known as autoimmune polyendocrinopathy candidiasis ectodermal dys- trophy syndrome (APECED) (Anderson and Su 2011). Like patients with APECED, AIREdeficient mice also develop spontaneous multiorgan autoimmune disease. In mTECs, the AIRE gene promotes expression of a wide array of TSAs (Anderson et al. 2002; Derbinski et al. 2005). mTECs also express B7 family costimulatory molecules, and perhaps not surprisingly, they can be efficient at inducing clonal deletion of $\mathrm{T}$ cells reactive to TSAs (Klein et al. 1998; Liston et al. 2003; Anderson et al. 2005). Although direct presentation of TSAs by mTECs was sufficient to induce clonal deletion of CD8SP thymocytes, it was not for CD4SP thymocytes (Gallegos and Bevan 2004). However, cross-presentation of mTEC-derived TSAs by DC can also occur, and that promotes deletion of both CD4 and CD8 SPs (Gallegos and Bevan 2004; Koble and Kyewski 2009).

AIRE contains a nuclear-localization signal, a proline-rich region, and other domains that are found in other transcription factors. The PHD1 domain of AIRE binds to unmethylated histone $\mathrm{H} 3$ at lysine-4 (H3K4me0) (Org et al. 2008). In addition, coimmunoprecipitation experiments showed that AIRE interacts with an unexpectedly large number of binding partners: proteins involved in pre-mRNA processing, transcription, nuclear transport, and chromatin binding and structure (Abramson et al.2010). AIRE plays a key function in regulating gene expression of TSAs, although how AIRE specifically promotes the presentation of tissue-specific antigens by MHC molecules remains enigmatic.

The role of AIRE in promoting tolerance may not be exclusively due to its ability to promote TSA expression. Even when AIRE deficiency did not affect TSA gene expression, it still affected clonal deletion (Anderson et al. 2005). AIRE-deficient mice have a disorganized medulla (Gillard et al. 2007; Dooley et al. 2008; Yano et al. 2008; Milicevic et al. 2009), with fewer medullary DCs (Lei et al. 2011), altered maturation of thymocytes (Sha et al. 1988), and reduced thymic export in the neonatal period (Laan et al. 2009). Interestingly, AIRE expression that was restricted solely to the neonatal period could prevent autoimmunity in AIRE knockout (KO) mice (Guerau-de-Arellano et al. 2009). 
Further work will be necessary to fully comprehend how gene deficiency in AIRE causes autoimmunity in humans.

In the thymus, several members of the TNF receptor superfamily, including the receptor activator of NF-кB (RANK), CD40, and lymphotoxin- $\beta$ receptor (LT $\beta \mathrm{R}$ ), are prominently expressed on mTECs, whereas their ligands, including RANKL, CD40L, and LT, are expressed on hematopoietic cells (Hikosaka et al. 2008). Recent observations indicate that positively selected thymocytes produce these cytokines, which act on mTECs to regulate their proliferation and differentiation to form the microenvironment of the thymic medulla, which is crucial for the establishment of self-tolerance (Akiyama et al. 2008; Hikosaka et al. 2008; Irla et al. 2008; Nitta et al. 2011). Both CD40L and RANKL activate the classical and alternative NF-kB signaling pathways. In addition, studies of genedeficient and mutant mice have clearly suggested that these pathways are involved in the development of mTECs, including: REL-B-deficient mice (Weih et al. 1995); Nik ${ }^{\text {aly } / \text { aly }}$ mice (Kajiura et al. 2004), which carry the alymphoplasia mutation in NF-кB-inducing kinase (Nik); tumor-necrosis factor-receptor-associated factor 6 (TRAF6)-deficient mice (Akiyama et al. 2005), and NF-кB2-deficient mice (Zhu et al.2006). All of these mutant mouse strains show reduced levels of AIRE, which promotes TSA expression by mTECs. mTECs might also contribute to central tolerance through their regulated expression of costimulatory molecules, such as CD40, CD80 (B7-1), and CD86 (B7-2) (Fig. 2).

\section{THYMIC APCs: DENDRITIC CELLS}

Like mTECs, the majority of thymic DCs also reside in the medulla, although there are some DCs in the cortex. Both medullary and cortical DCs are potentially important in central tolerance by inducing the apoptosis of self-reactive thymocytes. Thymic DCs are composed of three major subsets: $\mathrm{CD} 11 \mathrm{c}^{+} \mathrm{B} 220^{+}$plasmacytoid DCs (pDCs), CD $11 \mathrm{c}^{+} \mathrm{B} 220^{-} \mathrm{CD}^{-} \mathrm{a}^{-}$, signal regulatory protein $\operatorname{Sirp}^{+}$conventional DCs (cDCs), and $\mathrm{CD} 11 \mathrm{c}^{+} \mathrm{B} 220^{-} \mathrm{CD} 8 \alpha^{+}, \operatorname{Sirp} \alpha^{-}$ $\left(\mathrm{CD}^{+} \mathrm{DCs}\right)$. It is thought that most $\mathrm{CD} 8^{+}$
DCs develop intrathymically from a lymphoid pro-thymocyte precursor, whereas the $\mathrm{CD} 8 \alpha^{-}$ DC population, is thought to be of myeloid origin (Wu and Shortman 2005; Schlenner et al. 2010). Given that the majority of thymic DCs are found in the medulla, it is thought that the anatomical location of clonal deletion is generally in the medulla. However, in one model of clonal deletion to ubiquitous self-antigen, cortical DCs were shown to be important (McCaughtry and Hogquist 2008; McCaughtry et al. 2008). Interestingly, it has been reported that $\operatorname{Sirp} \alpha^{+}$cDCs are disseminated in the thymic cortex with some of them localized inside perivascular regions and nearby small vessels in the thymus, and it was suggested that they crucially contribute to central tolerance against bloodborne antigens (Baba et al. 2009; Atibalentja et al. 2011).

A unidirectional transfer of antigens was shown to occur in which thymic DCs specifically acquire self-antigen for cross-presentation from mTECs and not from hematopoietic sources (Gallegos and Bevan 2004; Koble and Kyewski 2009). A question arises as to how such antigens can load into the MHC Class II presentation pathway. A recent study has implicated autophagy as a means of antigen transfer, because mTECs appear to have autophagosomes and blocking autophagy in the thymus is associated with autoimmunity (Nedjic et al. 2008). However, further study is needed to establish the precise roles of distinct thymic DC subsets.

\section{MOLECULAR MECHANISMS OF CLONAL DELETION}

Thymocytes that recognize self-peptide-MHC with low affinity induce positive selection, whereas those with high affinity undergo negative selection (Fig. 1). This model, for which there is extensive experimental support, is known as an "affinity model" of selection (Starr et al. 2003). Thus a key question for understanding clonal deletion is how a TCR can discriminate between low- and high-affinity ligands. A simple model would be that low- and high-affinity signals are essentially the same, except that the threshold for positive selection is lower than for negative 
selection. This seems not to be the case, because preventing cell death after high-affinity signaling in the thymus was not sufficient to yield positive selection (Hu et al. 2009; Kovalovsky et al. 2010). Rather, the evidence suggests that low- and high-affinity interactions trigger qualitatively different responses. A "zipper" model was recently proposed, which suggests that highaffinity TCR-peptide-MHC interaction induces a stable "zippering" between the membraneproximal domain of $\mathrm{CD} 8 \beta$ and the connecting peptide motif of the $\alpha$-chain of the TCR $(\alpha-\mathrm{CPM})$, which then causes signal transduction leading to negative selection. Conversely, a low-affinity peptide-HC ligand that interacts with a TCR-coreceptor induces incomplete zippering and partial CD3 ITAM phosphorylation, consequently triggering positive selection (Palmer and Naeher 2009).

With respect to the downstream signals, the strength and kinetics of both $\mathrm{Ca}^{2+}$ and extracellular-signal-regulated kinase (ERK) signaling are important in positive versus negative selection. For example, negative selection induces a rapid and robust ERK activation that is associated with death, whereas positive selection stimulates a lower intensity but sustained ERK activation (McNeil et al. 2005). Further evidence suggests that the cellular location of ERK activation is also different under conditions of positive and negative selection (Daniels et al. 2006). A key protein, called Themis (thymocyte expressed molecule involved in selection), seems to be involved in determining the strength and kinetics of $\mathrm{Ca}^{2+}$ influx and phosphorylation of ERK (Fu et al. 2009; Johnson et al. 2009; Kakugawa et al. 2009; Lesourne et al. 2009; Patrick et al. 2009). Its deficiency markedly impairs positive selection of thymocytes. Interestingly, thymocytes seem to have a unique biochemical pathway that prevents them from undergoing death in response to low-affinity signals, which involves the protein Schnurri-2 (Staton et al. 2011). More work is needed to understand how these differences in proximal TCR signals lead to unique gene expression patterns and the distinct outcomes of life versus death.

Although important, TCR affinity is clearly not the only parameter that decides the life/ death fate of a thymocyte. cTECs are crucial for positive selection, although the reasons for this remain a mystery (Hogquist and Xing 2010). cTECs do express several unique genes that relate to proteolysis (Ctsl, TSSP, and $\beta 5 \mathrm{t}$ ) and are essential for positive selection. These genes likely contribute to a unique display of self-peptide ligands by cTECs, compared with other thymic APCs (Nakagawa et al. 1998; Honey et al. 2002; Murata et al. 2007; Gommeaux et al. 2009; Nitta et al. 2009; Viret et al. 2011). The fact that cells that support positive selection display distinct self-ligands compared with those that support negative selection may be a crucial part of the process, or it may simply enhance the numbers of progenitors that survive the gauntlet of thymic selection (Fig. 2).

Two genes that are consistently up-regulated in cells undergoing clonal deletion and can promote apoptosis are Nur77 and bim (Baldwin and Hogquist 2007). Nur77 is an orphan nuclear receptor that was originally suggested to be a key effector molecule in apoptosis (Woronicz et al. 1994). Overexpression was sufficient to induce apoptosis in DP thymocytes, and inhibition blocked clonal deletion in TCR transgenic models (Calnan et al. 1995). Nur77 can act as a transcriptional regulator, but recent work suggests that the influence of Nur77 in deletion may be via its ability to interact with BCL-2 family member proteinsin the mitochondria (Thompson and Winoto 2008), and not via inducing pro-apoptoticgenes. Although strongly expressed after highaffinity signaling in thymocytes, Nur77 is also expressed at low levels in positively selected $\mathrm{T}$ cells, suggesting a complex role in survival.

$\mathrm{Bim}$ is a pro-apoptotic member of the BCL2 family that mediates cell death by an intrinsic apoptotic pathway. Bim-deficient mice show impaired deletion of $\mathrm{T}$ cells reactive for superantigen (Bouillet et al. 2002; Villunger et al. 2004), tissue-specific antigen (Moran et al. 2011), and ubiquitous self-antigen ( $\mathrm{Hu}$ et al. 2009; Kovalovsky et al. 2010). Interestingly, in models of ubiquitous self-antigen, where deletion occurs at the $\mathrm{DP} \rightarrow \mathrm{SP}$ stage in the thymic cortex, elimination of Bim reduced the apoptosis of self-reactive thymocytes, but did not rescue their differentiation. The cells remained at 
the immature $\mathrm{CD} 4{ }^{\text {lo }} \mathrm{CD} 8{ }^{\text {lo }}$ stage of development (Hu et al. 2009; Kovalovsky et al. 2010). These data suggest a mechanistic distinction between positive and negative selection as discussed above. One implication of this fact is that failure of tolerance to ubiquitous antigens does not necessarily present a threat to the health of the animals, because thymocytes that receive high-affinity signals, but do not die, fail to be positively selected and do not become mature autoaggressive $\mathrm{T}$ cells. This is not the case for tissue-specific antigens, where deletion occurs at the medullary or SP stage. Thymocytes specific for TSA have already survived the positive selection checkpoint, and when they fail to be deleted (in this case, because of bim deficiency), autoreactive $\mathrm{T}$ cells accumulate (Moran et al. 2011). Whether this explains the prevalence of tissue-specific over systemic autoimmune diseases in humans remains to be determined. Although Bim induction is key to clonal deletion, it is not yet clear what TCR signals are required for its expression and why it is uniquely up-regulated after high-affinity TCR signaling. Furthermore, other molecules induced by TCR signaling in thymocytes, such as Nur77, may control the efficacy of BCL-2 family members such as Bim (Thompson and Winoto 2008).

Another class of molecules that contribute to clonal deletion is TCR costimulatory molecules. Experiments that used antibody-mediated costimulation through CD5, CD28, or CD43 in vitro strongly support this idea (Punt et al. 1994; Kishimoto and Sprent 1999). Yet, surprisingly, analysis of individual gene-deficient mice showed no effect or a mild effect on clonal deletion. It is possible that multiple costimulatory molecules act in a redundant fashion to promote apoptosis. More recent data suggest that CTLA-4 signaling in thymocytes may diminish the efficacy of clonal deletion (Buhlmann et al. 2003; Takahashi et al. 2005).

\section{CLONAL DIVERSION}

Foxp3-expressing CD4 T cells have been well characterized as regulatory $\mathrm{T}$ cells (Tregs). These cells suppress immune responses through nu- merous mechanisms including the production of anti-inflammatory cytokines, direct cell-cell contact, and by modulating the activation state and function of APCs (Shevach 2009). Mutations in the Forkhead box P3 (FOXP3) gene cause human immunodysregulation, polyendocrinopathy and enteropathy, X-linked syndrome (IPEX). In mouse models, Foxp3 is required for Treg development and maintenance of suppression function. Recognition of self-reactive TCR ligands appears to be a key event to initiate the Treg developmental program. Studies of transgenic mice with TCR specific to foreign antigens show that Treg develop only when the foreign antigen is also expressed in the thymus (Itoh et al. 1999; Jordan et al. 2001). Furthermore, studies using transgenic mice produced with TCR genes cloned from naturally occurring Tregs show that self-reactive TCR specificity is required for the instruction of Treg thymic differentiation in the thymus (Bautista et al. 2009; Leung et al. 2009). Thus, clonal deletion eliminates self-reactive clones from the repertoire, whereas clonal diversion imprints self-reactive clones with suppressive or regulatory function (Fig. 1). Thus, the former is sometimes referred to as "recessive" and the latter as "dominant" tolerance mechanisms. Because both clonal deletion and clonal diversion require TCR interaction with self-MHC ligands in the thymus, an interesting question is what distinguishes these processes?

In theory, distinct APCs might instruct the two processes. Because most Foxp3 expression is localized to the medulla, interest has focused on SP thymocytes and medullary APCs. Antigen presentation on mTECs was sufficient for the generation of antigen-specific Tregs, and antigen presentation on DCs, which could acquire and cross-present mTEC-derived antigen, was dispensable (Aschenbrenner et al. 2007). Other evidence showed that antigen expressed on thymic DCs could elicit Treg differentiation (Proietto et al. 2008; Hanabuchi et al. 2010). Thus, how thymic DCs and mTECs manage to elicit clonal deletion as well as clonal diversion remains to be determined and may reflect a complex interplay between both cell types (Lei et al. 2011). 
Y. Xing and K.A. Hogquist

\section{FACTORS IN THE DISTINCTION BETWEEN CLONAL DIVERSION AND CLONE DELETION}

TCR engagement is essential for both clonal deletion and Foxp3 induction during thymic differentiation of Tregs. TCR signals of distinct strength and duration have been proposed to explain this paradox, with stronger signals leading to deletion and weaker signals leading to diversion (Fig. 1). Experiments in a recently generated mouse model showed that reduction of MHC class II levels on mTECs through transgenic expression of a CIITA-specific microRNA diminished the efficacy of negative selection and led to the increased emergence of Tregs (Hinterberger et al. 2010). Furthermore, a TCR signal strength reporter mouse showed that cells undergoing clonal deletion showed greater ex- pression of the fluorescent reporter than Tregs (Moran et al. 2011). However, in addition to TCR signals, CD28 costimulation signals have an essential cell-intrinsic role in inducing the differentiation of Tregs (Tai et al. 2005; Lio et al. 2010), and IL-2 signaling is required for the survival of Tregs (Fig. 3) (Burchill et al. 2008; Lio and Hsieh 2008; Vang et al. 2008). It has long been appreciated that the cytokine TGF- $\beta$ can convert mature T cells into the socalled adaptive Treg lineage in the periphery, whereas its role in thymic commitment to the Treg lineage is less well studied. However, the combined absence of both TGF- $\beta$ and IL-2 signaling pathways led to a complete absence of thymic Treg (Liu et al. 2008). Interesting recent work suggests that TGF- $\beta$ might provide a protective effect to Tregs that are experiencing strong TCR signals from self-MHC, and thus be

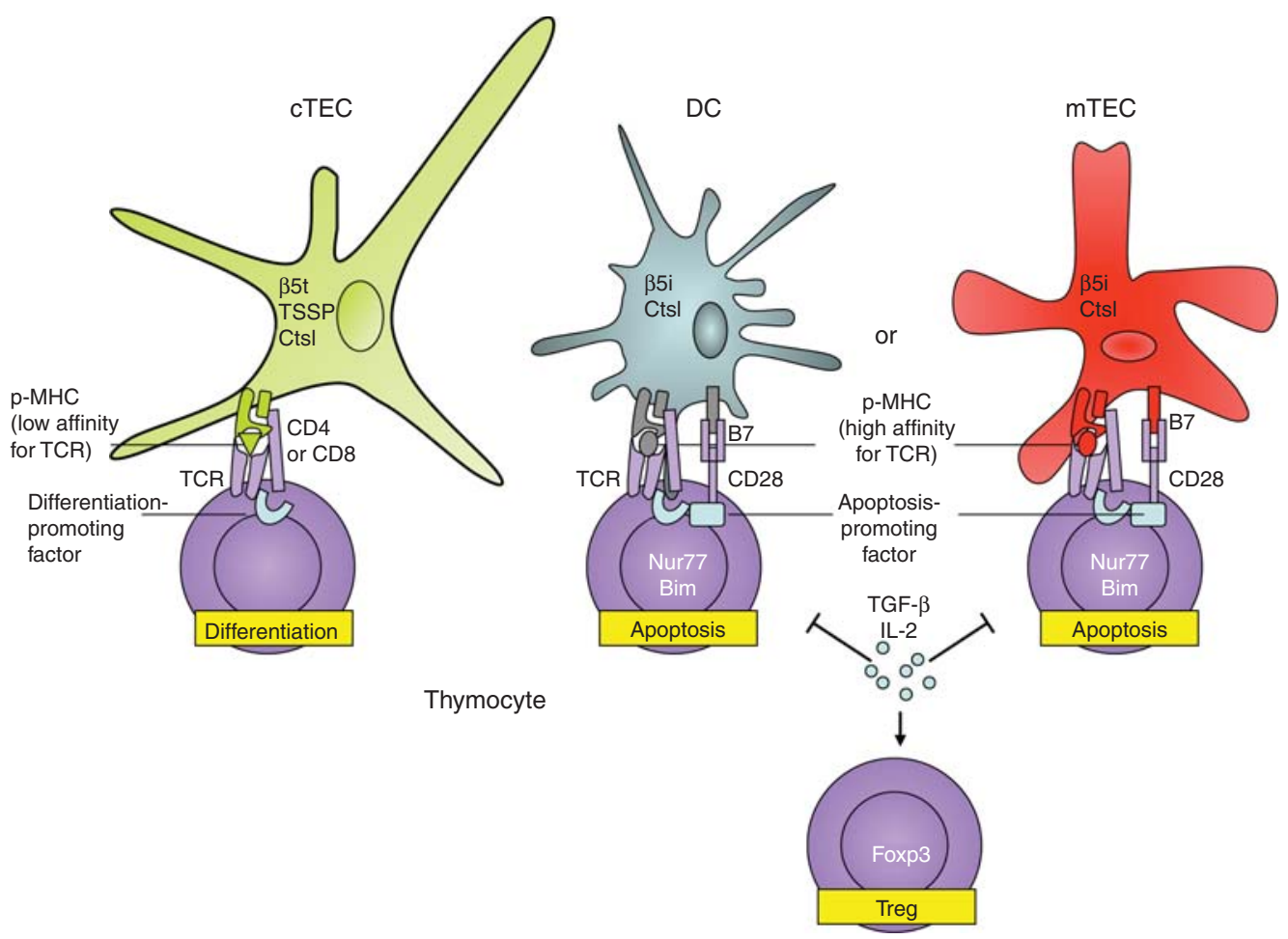

Figure 3. Differential TCR signaling in clonal deletion and clonal diversion. TCR engagement of low-affinity selfpeptide MHC ligands presented by cTECs transduces a signal that promotes survival and differentiation. TCR engagement with high-affinity self-peptide-MHC results in expression of Nur77 and Bim and apoptotic cell death. However, cytokines (TGF- $\beta$ and IL-2) can prevent Treg progenitors from undergoing apoptosis and promotes the differentiation of Tregs. 
another key signal in the discrimination between clonal deletion and clonal diversion (Ouyang et al. 2010). Clearly developing thymocytes integrate information from multiple inputs when deciding cell fate in the thymus.

\section{PERIPHERAL TOLERANCE}

Although central-tolerance mechanisms are efficient, they cannot eliminate all self-reactive lymphocytes, in part because not all self-antigens are expressed at the primary site of lymphocyte development-the thymus. Therefore, peripheral-tolerance mechanisms exist, and these are crucial to control tolerance of lymphocytes that first encounter their cognate self-antigens outside of the thymus - such as in the case of food antigens, developmental antigens, and antigens displayed during chronic infection. Both anergy and deletion of self-reactive $\mathrm{T}$ cells can occur in the periphery (Fig. 4).

\section{ANERGY}

$\mathrm{T}$ cells become activated in the presence of a TCR signal and a costimulatory signal mediated by CD28 ligation, and will then secret cytokines such as IL-2. Subsequent signaling through the IL-2R complex can fully activate the PI3K/AKTmTOR pathway. However, T-cell activation in the absence of a second signal induces a state of long-term hyporesponsiveness in $\mathrm{T}$ cells, termed "anergy," which is characterized by an active repression of TCR signaling and IL-2 expression.

Initial studies using the mTOR inhibitor rapamycin have shown that blocking mTOR activation is sufficient to induce anergy in T cells following full activation with anti-CD3 and anti-CD28. Recent studies suggest that several energy and nutrient-sensing pathways may be involved in the promotion of T-cell anergy through inhibiting mTOR activation (Powell and Delgoffe 2010). These include nutrient deprivation or activation of AMPK, a direct sensor of ATP deprivation and hypoxa, or mTORindependent pathways, such as the GCN2 amino acid-sensing pathway and adenosine signals through the $\mathrm{A} 2 \mathrm{~A}$ receptor (A2AR). Tregs have recently been postulated to promote a hypoxic environment via their expression of both the 5'-ectonucleotidease CD73 and the ATPase/ ADPase CD39 (Sitkovsky 2009; Chappert and Schwartz 2010). CD39 hydrolyzes ATP to AMP,
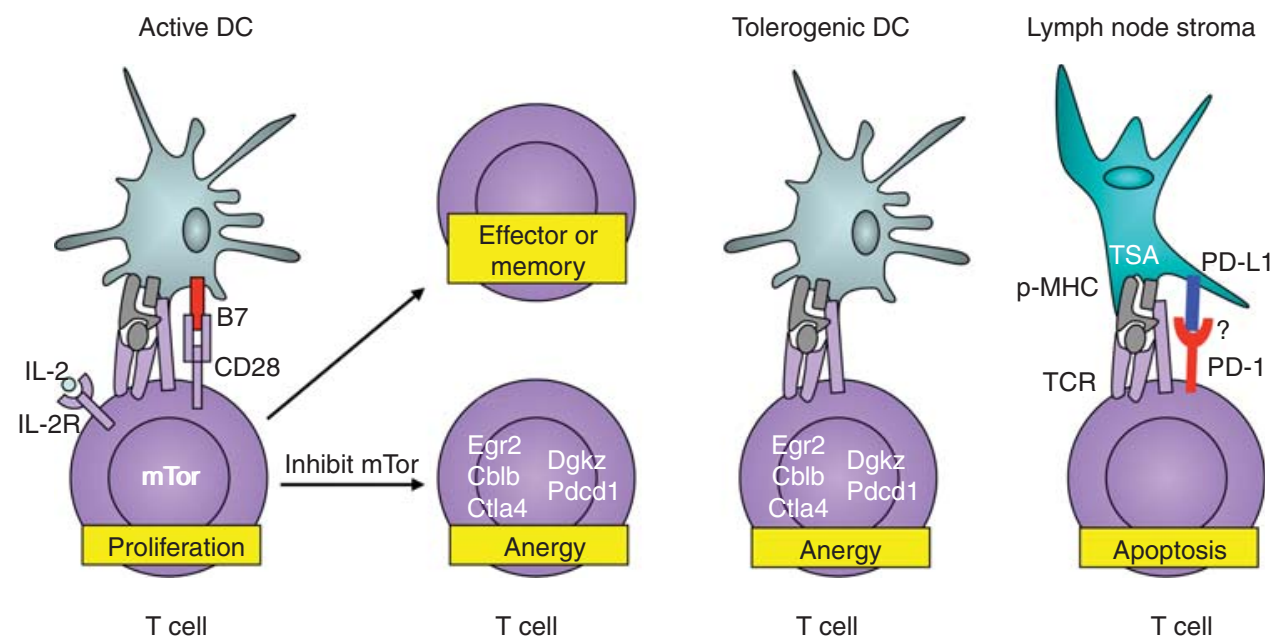

Figure 4. Peripheral tolerance. T-cell anergy is induced by inhibiting mTOR pathways or can be induced by tolerogenic DCs. The expression of Egr2, Cblb, Ctla4, DgkZ, and Pdcd1 genes is important in T-cell anergy. Lymph node stromal cells (LNSCs) express tissue-specific antigens (TSAs) and can mediate the deletion of selfreactive naive $\mathrm{T}$ cells. 
and CD73 converts AMP into adenosine. Tregs may thus regulate T-cell activation by anergy.

Costimulatory pathways provide second signals that promote T-cell activation as discussed above. However, they can also provide negative second signals that inhibit T-cell responses, mediate T-cell tolerance, and prevent autoimmunity. Key among these is the programmed death 1 (PD-1) receptor and its ligands PD-L1 and PD-L2 (Keir et al. 2008). Ligation of TCR and $\mathrm{PD}-1$ leads to the recruitment of phosphatases SHP-1 and SHP-2, which dephosphorylate proximal signaling molecules and effectively attenuate the activation of the PI3K and Akt pathways. The first evidence that PD-1 plays a critical role in control of self-reactivity came from the phenotype of mice lacking PD-1 $\left(\mathrm{Pdcd}^{-/-}\right)$, which develop a lupus-like autoimmune disease (Nishimura et al. 1999). Subsequent studies suggested that PD-1 interactions with its ligands PD-L1 and PD-L2 inhibit T-cell effector functions in an antigen-specific manner. This pathway can limit the initial phase of activation, the expansion of self-reactive T cells (Probst et al. 2005), or restrict self-reactive T-cell effector function and target organ injury, possibly via regulating dynamic $\mathrm{T}$-cell motility and the TCR stop signal (Fife and Pauken 2011). PD-1 signaling can also mediate the conversion of naive $\mathrm{T}$ cells to Tregs.

The other costimulatory molecule important in anergy is CTLA-4. CTLA-4 is induced late after T-cell activation and binds B7 family costimulatory molecules with high avidity. However, it transduces a negative signal and prevents cell cycle progression. CTLA-4-deficient mice show spontaneous autoimmunity (Tivol et al. 1995; Waterhouse et al. 1995), and Ctla4 ${ }^{-/-}$ CD4 T cells resist anergy induction (Perez et al. 1997). Like PD-1, part of the role of CTLA-4 in peripheral tolerance relates to its role in regulatory $\mathrm{T}$ cells. Clinical approaches that focus on costimulatory molecules are discussed in Bluestone (2012).

Several other genes are uniquely induced in anergic cells (Macian et al. 2002) and are functionally important for the anergic state, including Cbl-b, p27Kip1, Dgkz, Egr2/3, Itch, NFAT1, Tob1, and Grail. Interestingly, microarray anal- ysis showed significant similarity in the gene expression profiles of cells undergoing peripheral deletion and anergy induction (Parish et al. 2009).

\section{TOLEROGENIC APCS}

Peripheral DCs are inducers of immune responses, but are also crucial regulators of tolerance induction and maintenance. Tolerogenic DCs present antigen to antigen-specific $\mathrm{T}$ cells, but fail to deliver adequate costimulatory signals (or deliver net coinhibitory signals) for Tcell activation and proliferation (Gallucci et al. 1999). DC tolerogenicity is not specific to a single DC subset. Evidence suggests that tolerogenic DCs are generated by incomplete maturation. For example, apoptotic cells, unlike necrotic cells, are insufficient to trigger DC maturation (Hawiger et al. 2001) through suppressing the activation of NF-kB pathways mediated by TLR and cytokine receptor. PD-L1 and PD-L2 can be expressed on tolerogenic DCs, providing a means to control the decision between T-cell activation and tolerance. Tolerogenic DCs can also be induced and maintained by various anti-inflammatory and immunosuppressive agents in vitro and in vivo, including IL-10, TGF $\beta 1$, corticosteroids, and rapamycin (Morelli and Thomson 2007). Targeting and manipulating tolerogenic DCs has been shown to suppress experimental autoimmune disease and promote improved outcomes of transplantation; this is discussed in greater detail in Reizis (2012).

Lymph node stromal cells (LNSCs) were once thought to function solely as parenchymal support to lymphocytes. However, new evidence shows that all types of LNSCs-including fibroblastic reticular cells (FRCs), follicular DCs (FDCs), and lymphatic endothelial cells (LECs)—express TSA (Fletcher et al. 2011). Recently, an extrathymic AIRE-expressing stromal cell population (eTAC) in lymph nodes was identified that lacks expression of CD80 and CD86 (Gardner et al. 2008). Interestingly, microarray experiments show that AIRE-dependent TSAs in peripheral eTACs and thymic mTECs are largely distinct. The ability of eTACs (Gardner et al. 
T-Cell Tolerance

2009; Fletcher et al. 2010) and other LNSCs (Cohen et al. 2010) to promote tolerance has been shown primarily in transgenic mouse model systems. Although the mechanisms need to be more fully explored, in these models, LNSCs could directly present antigens to $\mathrm{CD} 8^{+} \mathrm{T}$ cells, which were subsequently deleted.

\section{PERIPHERAL DELETION}

Deletion of self-reactive lymphocytes in both the thymus and the periphery is achieved through apoptotic cell death. Both Fas- and Bim-mediated apoptosis pathways appear to be important for self-reactive lymphocytes in the periphery. Although Fas-mediated "death receptor" signaling and "BCL-2-regulated" apoptosis signaling are mechanistically distinct, these pathways are coordinated and cooperate in the killing of $\mathrm{T}$ lymphocytes chronically stimulated by self-antigens in vivo.

Fas (CD95) is a death-domain-containing receptor, and can be activated by its corresponding ligand FasL (CD178) or agonistic antibodies. Mice lacking either of these proteins (Fas-deficient $l p r$ or $l p r^{c g}$ mice or FasL-deficient gld mice) develop progressive lymphadenopathy and splenomegaly (Cohen and Eisenberg 1991). T cells express Fas, and the expression of FasL is induced on $T$ cells after activation by antigen and IL-2. Fas was shown to be critical for the deletion of $\mathrm{T}$ cells that had been stimulated repeatedly by their cognate or foreign antigen in vivo (Kawabe and Ochi 1991; Strasser and Pellegrini 2004). The activation of Fas triggers formation of an intracellular "death-inducing signaling complex" (DISC); in turn, active Caspase-8 and effector caspases consequently promote apoptosis. This pathway of apoptosis is called activationinduced cell death (AICD). Bim is able to directly activate Bax/Bak to cause permeabilization of the outer mitochondrial membrane and induce apoptosis. In contrast to AICD, the killing of antigen-activated T cells during shutdown of an immune response to an acute infection requires Bim, but not Fas (Hildeman et al. 2002; Pellegrini et al. 2003). Bim-deficient aging mice spontaneously develop immune complex-glomerulonephritis (Bouillet et al. 2002).

\section{CONCLUDING REMARKS}

In summary, tremendous progress has been made in understanding the cellular and molecular basis of central and peripheral tolerance. This research has led to an understanding of the pathogenesis of at least two human inherited autoimmune diseases and many promising therapeutic strategies.

\section{REFERENCES}

${ }^{*}$ Reference is also in this collection.

Abramson J, Giraud M, Benoist C, Mathis D. 2010. Aire's partners in the molecular control of immunological tolerance. Cell 140: 123-135.

Akiyama T, Maeda S, Yamane S, Ogino K, Kasai M, Kajiura F, Matsumoto M, Inoue J. 2005. Dependence of self-tolerance on TRAF6-directed development of thymic stroma. Science 308: 248-251.

Akiyama T, Shimo Y, Yanai H, Qin J, Ohshima D, Maruyama Y, Asaumi Y, Kitazawa J, Takayanagi H, Penninger JM, et al. 2008. The tumor necrosis factor family receptors RANK and CD40 cooperatively establish the thymic medullary microenvironment and self-tolerance. Immunity 29: 423-437.

Anderson MS, Su MA. 2011. Aire and T cell development. Curr Opin Immunol 23: 198-206.

Anderson MS, Venanzi ES, Klein L, Chen Z, Berzins SP, Turley SJ, von Boehmer H, Bronson R, Dierich A, Benoist C, et al. 2002. Projection of an immunological self shadow within the thymus by the Aire protein. Science 298: 1395-1401.

Anderson MS, Venanzi ES Chen Z, Berzins SP, Benoist C, Mathis D. 2005. The cellular mechanism of Aire control of T cell tolerance. Immunity 23: 227-239.

Aschenbrenner K, D’Cruz LM, Vollmann EH, Hinterberger M, Emmerich J, Swee LK, Rolink A, Klein L. 2007. Selection of Foxp $3^{+}$regulatory T cells specific for self antigen expressed and presented by Aire ${ }^{+}$medullary thymic epithelial cells. Nat Immunol 8: 351-358.

Atibalentja DF, Murphy KM, Unanue ER. 2011. Functional redundancy between thymic $\mathrm{CD} 8 \alpha^{+}$and Sirp $\alpha^{+}$conventional dendritic cells in presentation of blood-derived lysozyme by MHC class II proteins. J Immunol 186: 1421-1431.

Baba T, Nakamoto Y, Mukaida N. 2009. Crucial contribution of thymic Sirp $\alpha^{+}$conventional dendritic cells to central tolerance against blood-borne antigens in a CCR2-dependent manner. J Immunol 183: 3053-3063.

Baldwin TA, Hogquist KA. 2007. Transcriptional analysis of clonal deletion in vivo. J Immunol 179: 837-844.

Baldwin TA, Sandau MM, Jameson SC, Hogquist KA. 2005. The timing of TCR $\alpha$ expression critically influences T cell development and selection. J Exp Med 202: $111-121$.

Bautista JL, Lio CW, Lathrop SK, Forbush K, Liang Y, Luo J, Rudensky AY, Hsieh CS. 2009. Intraclonal competition 
limits the fate determination of regulatory $\mathrm{T}$ cells in the thymus. Nat Immunol 10: 610-617.

* Benoist C, Mathis D. 2012. Tregs cells, life history, and diversity. Cold Spring Harb Perspect Biol doi: 10.1101/ cshperspect.a007021.

* Bluestone JA, Bour-Jordan H. 2012. Current and future immunomodulation strategies to restore tolerance in autoimmune diseases. Cold Spring Harb Perspect Biol doi: 10.1101/cshperspect.a007542.

Bouillet P, Purton JF, Godfrey DI, Zhang LC, Coultas L, Puthalakath H, Pellegrini M, Cory S, Adams JM, Strasser A. 2002. BH3-only Bcl-2 family member Bim is required for apoptosis of autoreactive thymocytes. Nature 415: 922-926.

Buch T, Rieux-Laucat F, Forster I, Rajewsky K. 2002. Failure of HY-specific thymocytes to escape negative selection by receptor editing. Immunity 16: 707-718.

Buhlmann JE, Elkin SK, Sharpe AH. 2003. A role for the B71/B7-2:CD28/CTLA-4 pathway during negative selection. J Immunol 170: 5421-5428.

Burchill MA, Yang J, Vang KB, Moon JJ, Chu HH, Lio CW, Vegoe AL, Hsieh CS, Jenkins MK, Farrar MA. 2008. Linked $\mathrm{T}$ cell receptor and cytokine signaling govern the development of the regulatory $\mathrm{T}$ cell repertoire. Immunity 28: 112-121.

Calnan BJ, Szychowski S, Chan FK, Cado D, Winoto A. 1995. A role for the orphan steroid receptor Nur77 in apoptosis accompanying antigen-induced negative selection. Immunity 3: 273-282.

Chappert P, Schwartz RH. 2010. Induction of T cell anergy: Integration of environmental cues and infectious tolerance. Curr Opin Immunol 22: 552-559.

Cohen PL, Eisenberg RA. 1991. $l p r$ and $g l d$ : Single gene models of systemic autoimmunity and lymphoproliferative disease. Annu Rev Immunol 9: 243-269.

Cohen JN, Guidi CJ, Tewalt EF, Qiao H, Rouhani SJ, Ruddell A, Farr AG, Tung KS, Engelhard VH. 2010. Lymph noderesident lymphatic endothelial cells mediate peripheral tolerance via Aire-independent direct antigen presentation. J Exp Med 207: 681-688.

Daniels MA, Teixeiro E, Gill J, Hausmann B, Roubaty D, Holmberg K, Werlen G, Hollander GA, Gascoigne NR, Palmer E. 2006. Thymic selection threshold defined by compartmentalization of Ras/MAPK signalling. Nature 444: 724-729.

Derbinski J, Schulte A, Kyewski B, Klein L. 2001. Promiscuous gene expression in medullary thymic epithelial cells mirrors the peripheral self. Nat Immunol 2: 1032-1039.

Derbinski J, Gabler J, Brors B, Tierling S, Jonnakuty S, Hergenhahn M, Peltonen L, Walter J, Kyewski B. 2005. Promiscuous gene expression in thymic epithelial cells is regulated at multiple levels. J Exp Med 202: 33-45.

Dooley J, Erickson M, Farr AG. 2008. Alterations of the medullary epithelial compartment in the Aire-deficient thymus: Implications for programs of thymic epithelial differentiation. J Immunol 181: 5225-5232.

Egawa T, Kreslavsky T, Littman DR, von Boehmer H. 2008. Lineage diversion of $\mathrm{T}$ cell receptor transgenic thymocytes revealed by lineage fate mapping. PLOS ONE 3: e1512.
Fife BT, Pauken KE. 2011. The role of the PD-1 pathway in autoimmunity and peripheral tolerance. Ann NY Acad Sci 1217: 45-59.

Fletcher AL, Lukacs-Kornek V, Reynoso ED, Pinner SE, Bellemare-Pelletier A, Curry MS, Collier AR, Boyd RL, Turley SJ. 2010. Lymph node fibroblastic reticular cells directly present peripheral tissue antigen under steady-state and inflammatory conditions. J Exp Med 207: 689-697.

Fletcher AL, Malhotra D, Turley SJ. 2011. Lymph node stroma broaden the peripheral tolerance paradigm. Trends Immunol 32: 12-18.

Fu G, Vallee S, Rybakin V, McGuire MV, Ampudia J, Brockmeyer C, Salek M, Fallen PR, Hoerter JA, Munshi A, et al. 2009. Themis controls thymocyte selection through regulation of T cell antigen receptor-mediated signaling. Nat Immunol 10: 848-856.

Gallegos AM, Bevan MJ. 2004. Central tolerance to tissuespecific antigens mediated by direct and indirect antigen presentation. J Exp Med 200: 1039-1049.

Gallucci S, Lolkema M, Matzinger P. 1999. Natural adjuvants: Endogenous activators of dendritic cells. Nat Med 5: 1249-1255.

Gardner JM, Devoss JJ, Friedman RS, Wong DJ, Tan YX, Zhou X, Johannes KP, Su MA, Chang HY, Krummel MF, et al. 2008. Deletional tolerance mediated by extrathymic Aire-expressing cells. Science 321: 843-847.

Gardner JM, Fletcher AL, Anderson MS, Turley SJ. 2009. AIRE in the thymus and beyond. Curr Opin Immunol 21: $582-589$.

Gillard GO, Dooley J, Erickson M, Peltonen L, Farr AG. 2007. Aire-dependent alterations in medullary thymic epithelium indicate a role for Aire in thymic epithelial differentiation. J Immunol 178: 3007-3015.

Gommeaux J, Gregoire C, Nguessan P, Richelme M, Malissen M, Guerder S, Malissen B, Carrier A. 2009. Thymusspecific serine protease regulates positive selection of a subset of $\mathrm{CD}^{+}{ }^{+}$thymocytes. Eur J Immunol 39: 956-964.

Gotter J, Brors B, Hergenhahn M, Kyewski B. 2004. Medullary epithelial cells of the human thymus express a highly diverse selection of tissue-specific genes colocalized in chromosomal clusters. J Exp Med 199: 155-166.

Guerau-de-Arellano M, Martinic M, Benoist C, Mathis D. 2009. Neonatal tolerance revisited: A perinatal window for Aire control of autoimmunity. J Exp Med 206: $1245-$ 1252.

Hanabuchi S, Ito T, Park WR, Watanabe N, Shaw JL, Roman E, Arima K, Wang YH, Voo KS, Cao W, et al. 2010. Thymic stromal lymphopoietin-activated plasmacytoid dendritic cells induce the generation of $\mathrm{FOXP}^{+}$regulatory T cells in human thymus. J Immunol 184: 2999-3007.

Hawiger D, Inaba K, Dorsett Y, Guo M, Mahnke K, Rivera M, Ravetch JV, Steinman RM, Nussenzweig MC. 2001. Dendritic cells induce peripheral T cell unresponsiveness under steady state conditions in vivo. J Exp Med 194: 769-779.

Hikosaka Y, Nitta T, Ohigashi I, Yano K, Ishimaru N, Hayashi Y, Matsumoto M, Matsuo K, Penninger JM, Takayanagi $\mathrm{H}$, et al. 2008. The cytokine RANKL produced by positively selected thymocytes fosters medullary thymic epithelial cells that express autoimmune regulator. Immunity 29: 438-450. 
Hildeman DA, Zhu Y, Mitchell TC, Bouillet P, Strasser A, Kappler J, Marrack P. 2002. Activated T cell death in vivo mediated by proapoptotic bcl-2 family member bim. Immunity 16: 759-767.

Hinterberger M, Aichinger M, da Costa OP, Voehringer D, Hoffmann R, Klein L. 2010. Autonomous role of medullary thymic epithelial cells in central $\mathrm{CD} 4^{+} \mathrm{T}$ cell tolerance. Nat Immunol 11: 512-519.

Hogquist KA, Xing Y. 2010. Why CD8 ${ }^{+}$T cells need diversity when growing up. Immunity 32: 5-6.

Holman PO, Walsh ER, Hogquist KA. 2003. The central tolerance response to male antigen in normal mice is deletion and not receptor editing. J Immunol 171: $4048-4053$.

Honey K, Nakagawa T, Peters C, Rudensky A. 2002. Cathepsin $\mathrm{L}$ regulates $\mathrm{CD} 4^{+} \mathrm{T}$ cell selection independently of its effect on invariant chain: A role in the generation of positively selecting peptide ligands. J Exp Med 195: 1349-1358.

Hu Q, Sader A, Parkman JC, Baldwin TA. 2009. Bimmediated apoptosis is not necessary for thymic negative selection to ubiquitous self-antigens. J Immunol 183: 7761-7767.

Irla M, Hugues S, Gill J, Nitta T, Hikosaka Y, Williams IR, Hubert FX, Scott HS, Takahama Y, Hollander GA, et al. 2008. Autoantigen-specific interactions with $\mathrm{CD}^{+}$thymocytes control mature medullary thymic epithelial cell cellularity. Immunity 29: 451-463.

Itoh M, Takahashi T, Sakaguchi N, Kuniyasu Y, Shimizu J, Otsuka F, Sakaguchi S. 1999. Thymus and autoimmunity: Production of $\mathrm{CD} 25^{+} \mathrm{CD} 4^{+}$naturally anergic and suppressive $\mathrm{T}$ cells as a key function of the thymus in maintaining immunologic self-tolerance. J Immunol 162: $5317-5326$.

Johnson AL, Aravind L, Shulzhenko N, Morgun A, Choi SY, Crockford TL, Lambe T, Domaschenz H, Kucharska EM, Zheng L, et al. 2009. Themis is a member of a new metazoan gene family and is required for the completion of thymocyte positive selection. Nat Immunol 10: 831-839.

Jordan MS, Boesteanu A, Reed AJ, Petrone AL, Holenbeck AE, Lerman MA, Naji A, Caton AJ. 2001. Thymic selection of $\mathrm{CD} 4^{+} \mathrm{CD} 25^{+}$regulatory $\mathrm{T}$ cells induced by an agonist self-peptide. Nat Immunol 2: 301-306.

Kajiura F, Sun S, Nomura T, Izumi K, Ueno T, Bando Y, Kuroda N, Han H, Li Y, Matsushima A, et al. 2004. NF$\kappa \mathrm{B}$-inducing kinase establishes self-tolerance in a thymic stroma-dependent manner. J Immunol 172: 2067-2075.

Kakugawa K, Yasuda T, Miura I, Kobayashi A, Fukiage H, Satoh R, Matsuda M, Koseki H, Wakana S, Kawamoto H, et al. 2009. A novel gene essential for the development of single positive thymocytes. Mol Cell Biol 29: 5128-5135.

Kappler JW, Roehm N, Marrack P. 1987. T cell tolerance by clonal elimination in the thymus. Cell 49: 273-280.

Kawabe Y, Ochi A. 1991. Programmed cell death and extrathymic reduction of $\mathrm{V} \beta 8^{+} \mathrm{CD} 4^{+} \mathrm{T}$ cells in mice tolerant to Staphylococcus aureus enterotoxin B. Nature 349: 245-248.

Keir ME, Butte MJ, Freeman GJ, Sharpe AH. 2008. PD-1 and its ligands in tolerance and immunity. Annu Rev Immunol 26: 677-704.
Kishimoto H, Sprent J. 1999. Several different cell surface molecules control negative selection of medullary thymocytes. J Exp Med 190: 65-73.

Kisielow P, Bluthmann H, Staerz UD, Steinmetz M, von Boehmer H. 1988. Tolerance in T-cell-receptor transgenic mice involves deletion of nonmature $\mathrm{CD} 4^{+} 8^{+}$thymocytes. Nature 333: 742-746.

Klein L, Klein T, Ruther U, Kyewski B. 1998. CD4 T cell tolerance to human C-reactive protein, an inducible serum protein, is mediated by medullary thymic epithelium. J Exp Med 188: 5-16.

Koble C, Kyewski B. 2009. The thymic medulla: A unique microenvironment for intercellular self-antigen transfer. J Exp Med 206: 1505-1513.

Kovalovsky D, Pezzano M, Ortiz BD, Sant'Angelo DB. 2010. A novel TCR transgenic model reveals that negative selection involves an immediate, Bim-dependent pathway and a delayed, Bim-independent pathway. PLoS ONE 5: e8675.

Laan M, Kisand K, Kont V, Moll K, Tserel L, Scott HS, Peterson P. 2009. Autoimmune regulator deficiency results in decreased expression of CCR4 and CCR7 ligands and in delayed migration of $\mathrm{CD} 4^{+}$thymocytes. J Immunol 183: 7682-7691.

Lei Y, Ripen AM, Ishimaru N, Ohigashi I, Nagasawa T, Jeker LT, Bosl MR, Hollander GA, Hayashi Y, Malefyt Rde W, et al. 2011. Aire-dependent production of XCL1 mediates medullary accumulation of thymic dendritic cells and contributes to regulatory T cell development. J Exp Med 208: $383-394$.

Lesourne R, Uehara S, Lee J, Song KD, Li L, Pinkhasov J, Zhang Y, Weng NP, Wildt KF, Wang L, et al. 2009. Themis, a $\mathrm{T}$ cell-specific protein important for late thymocyte development. Nat Immunol 10: 840-847.

Leung MW, Shen S, Lafaille JJ. 2009. TCR-dependent differentiation of thymic Foxp $3^{+}$cells is limited to small clonal sizes. J Exp Med 206: 2121-2130.

Lio CW, Hsieh CS. 2008. A two-step process for thymic regulatory T cell development. Immunity 28: 100-111.

Lio CW, Dodson LF, Deppong CM, Hsieh CS, Green JM. 2010. CD28 facilitates the generation of Foxp $3^{-}$cytokine responsive regulatory $\mathrm{T}$ cell precursors. J Immunol 184: 6007-6013.

Liston A, Lesage S, Wilson J, Peltonen L, Goodnow CC. 2003. Aire regulates negative selection of organ-specific T cells. Nat Immunol 4: 350-354.

Liu Y, Zhang P, Li J, Kulkarni AB, Perruche S, Chen W. 2008. A critical function for TGF- $\beta$ signaling in the development of natural $\mathrm{CD} 4^{+} \mathrm{CD} 25^{+}$Foxp $3^{+}$regulatory $\mathrm{T}$ cells. Nat Immunol 9: 632-640.

Macian F, Garcia-Cozar F, Im SH, Horton HF, Byrne MC, Rao A. 2002. Transcriptional mechanisms underlying lymphocyte tolerance. Cell 109: 719-731.

McCaughtry TM, Hogquist KA. 2008. Central tolerance: What have we learned from mice? Semin Immunopathol 30: 399-409.

McCaughtry TM, Baldwin TA, Wilken MS, Hogquist KA. 2008. Clonal deletion of thymocytes can occur in the cortex with no involvement of the medulla. J Exp Med 205: $2575-2584$. 
McGargill MA, Derbinski JM, Hogquist KA. 2000. Recepto editing in developing T cells. Nat Immunol 1: 336-341.

McGargill MA, Mayerova D, Stefanski HE, Koehn B, Parke EA, Jameson SC, Panoskaltsis-Mortari A, Hogquist KA. 2002. A spontaneous CD8 T cell-dependent autoimmune disease to an antigen expressed under the human keratin 14 promoter. J Immunol 169: 2141-2147.

McNeil LK, Starr TK, Hogquist KA. 2005. A requirement for sustained ERK signaling during thymocyte positive selection in vivo. Proc Natl Acad Sci 102: 13574-13579.

Milicevic Z, Milicevic NM, Laan M, Peterson P, Kisand K, Scott HS, Westermann J. 2009. Ultrastructure of medullary thymic epithelial cells of autoimmune regulator (Aire)-deficient mice. Immunol Cell Biol 88: 50-56.

Moran AE, Holzapfel KL, Xing Y, Cunningham NR, Maltzman JS, Punt J, Hogquist KA. 2011. T cell receptor signal strength in Treg and iNKT cell development demonstrated by a novel fluorescent reporter mouse. J Exp Med 8: 1279-1289.

Morelli AE, Thomson AW. 2007. Tolerogenic dendritic cells and the quest for transplant tolerance. Nat Rev Immunol 7: 610-621.

Murata S, Sasaki K, Kishimoto T, Niwa S, Hayashi H, Takahama Y, Tanaka K. 2007. Regulation of $\mathrm{CD}^{+} \mathrm{T}$ cell development by thymus-specific proteasomes. Science 316: 1349-1353.

Nakagawa T, Roth W, Wong P, Nelson A, Farr A, Deussing J, Villadangos JA, Ploegh H, Peters C, Rudensky AY. 1998. Cathepsin L: Critical role in Ii degradation and CD4 T cell selection in the thymus. Science 280: 450-453.

Nedjic J, Aichinger M, Emmerich J, Mizushima N, Klein L. 2008. Autophagy in thymic epithelium shapes the T-cell repertoire and is essential for tolerance. Nature 455: 396-400.

Nishimura H, Nose M, Hiai H, Minato N, Honjo T. 1999. Development of lupus-like autoimmune diseases by disruption of the PD-1 gene encoding an ITIM motif-carrying immunoreceptor. Immunity 11: 141-151.

Nitta T, Murata S, Sasaki K, Fujii H, Ripen AM, Ishimaru N, Koyasu S, Tanaka K, Takahama Y. 2009. Thymoproteasome shapes immunocompetent repertoire of $\mathrm{CD}^{+} \mathrm{T}$ cells. Immunity 32: 29-40.

Nitta T, Ohigashi I, Nakagawa Y, Takahama Y. 2011. Cytokine crosstalk for thymic medulla formation. Curr Opin Immunol 23: 190-197.

Org T, Chignola F, Hetenyi C, Gaetani M, Rebane A, Liiv I, Maran U, Mollica L, Bottomley MJ, Musco G, et al. 2008. The autoimmune regulator PHD finger binds to nonmethylated histone $\mathrm{H} 3 \mathrm{~K} 4$ to activate gene expression. EMBO Rep 9: 370-376.

Ouyang W, Beckett O, Ma Q, Li MO. 2010. Transforming growth factor- $\beta$ signaling curbs thymic negative selection promoting regulatory $\mathrm{T}$ cell development. Immunity 32: 642-653.

Palmer E, Naeher D. 2009. Affinity threshold for thymic selection through a T-cell receptor-co-receptor zipper. Nat Rev Immunol 9: 207-213.

Parish IA, Rao S, Smyth GK, Juelich T, Denyer GS, Davey GM, Strasser A, Heath WR. 2009. The molecular signature of $\mathrm{CD}^{+} \mathrm{T}$ cells undergoing deletional tolerance. Blood 113: 4575-4585.
Patrick MS, Oda H, Hayakawa K, Sato Y, Eshima K, Kirikae T, Iemura S, Shirai M, Abe T, Natsume T, et al. 2009. Gasp, a Grb2-associating protein, is critical for positive selection of thymocytes. Proc Natl Acad Sci 106: 1634516350.

Pellegrini M, Belz G, Bouillet P, Strasser A. 2003. Shutdown of an acute $\mathrm{T}$ cell immune response to viral infection is mediated by the proapoptotic Bcl-2 homology 3-only protein Bim. Proc Natl Acad Sci 100: 14175-14180.

Perez VL, Van Parijs L, Biuckians A, Zheng XX, Strom TB, Abbas AK. 1997. Induction of peripheral T cell tolerance in vivo requires CTLA-4 engagement. Immunity 6: 411417.

Powell JD, Delgoffe GM. 2010. The mammalian target of rapamycin: Linking $\mathrm{T}$ cell differentiation, function, and metabolism. Immunity 33: 301-311.

Probst HC, McCoy K, Okazaki T, Honjo T, van den Broek M. 2005. Resting dendritic cells induce peripheral $\mathrm{CD}^{+} \mathrm{T}$ cell tolerance through PD-1 and CTLA-4. Nat Immunol 6: $280-286$.

Proietto AI, van Dommelen S, Zhou P, Rizzitelli A, D’Amico A, Steptoe RJ, Naik SH, Lahoud MH, Liu Y, Zheng P, et al. 2008. Dendritic cells in the thymus contribute to T-regulatory cell induction. Proc Natl Acad Sci 105: 1986919874.

Punt JA, Osborne BA, Takahama Y, Sharrow SO, Singer A. 1994. Negative selection of $\mathrm{CD} 4^{+} \mathrm{CD} 8^{+}$thymocytes by $\mathrm{T}$ cell receptor-induced apoptosis requires a costimulatory signal that can be provided by CD28. J Exp Med 179: 709-713.

Santori FR, Arsov I, Lilic M, Vukmanovic S. 2002. Editing autoreactive TCR enables efficient positive selection. $J$ Immunol 169: 1729-1734.

Schlenner SM, Madan V, Busch K, Tietz A, Laufle C, Costa C, Blum C, Fehling HJ, Rodewald HR. 2010. Fate mapping reveals separate origins of $\mathrm{T}$ cells and myeloid lineages in the thymus. Immunity 32: 426-436.

Sha WC, Nelson CA, Newberry RD, Kranz DM, Russell JH, Loh DY. 1988. Positive and negative selection of an antigen receptor on T cells in transgenic mice. Nature 336: 73-76.

Shevach EM. 2009. Mechanisms of Foxp $3^{+}$Tregulatory cellmediated suppression. Immunity 30: 636-645.

Sitkovsky MV. 2009. T regulatory cells: Hypoxia-adenosinergic suppression and re-direction of the immune response. Trends Immunol 30: 102-108.

Starr TK, Jameson SC, Hogquist KA. 2003. Positive and negative selection of T cells. Annu Rev Immunol 21: 139-176.

Staton TL, Lazarevic V, Jones DC, Lanser AJ, Takagi T, Ishii S, Glimcher LH. 2011. Dampening of death pathways by schnurri-2 is essential for T-cell development. Nature 472: 105-109.

Strasser A, Pellegrini M. 2004. T-lymphocyte death during shutdown of an immune response. Trends Immunol 25: $610-615$.

Tai X, Cowan M, Feigenbaum L, Singer A. 2005. CD28 costimulation of developing thymocytes induces Foxp3 expression and regulatory $\mathrm{T}$ cell differentiation independently of interleukin 2. Nat Immunol 6: 152-162. 
T-Cell Tolerance

Takahashi S, Kataoka H, Hara S, Yokosuka T, Takase K, Yamasaki S, Kobayashi W, Saito Y, Saito T. 2005. In vivo overexpression of CTLA-4 suppresses lymphoproliferative diseases and thymic negative selection. Eur J Immunol 35: 399-407.

Thompson J, Winoto A. 2008. During negative selection, Nur77 family proteins translocate to mitochondria where they associate with Bcl-2 and expose its proapoptotic BH3 domain. J Exp Med 205: 1029-1036.

Tivol EA, Borriello F, Schweitzer AN, Lynch WP, Bluestone JA, Sharpe AH. 1995. Loss of CTLA-4 leads to massive lymphoproliferation and fatal multiorgan tissue destruction, revealing a critical negative regulatory role of CTLA4. Immunity 3: 541-547.

Vang KB, Yang J, Mahmud SA, Burchill MA, Vegoe AL, Farrar MA. 2008. IL-2, -7, and -15, but not thymic stromal lymphopoeitin, redundantly govern $\mathrm{CD}^{+}{ }^{+} \mathrm{Foxp}^{+}$ regulatory T cell development. J Immunol 181: 32853290.

Villunger A, Marsden VS, Zhan Y, Erlacher M, Lew AM, Bouillet P, Berzins S, Godfrey DI, Heath WR, Strasser A. 2004. Negative selection of semimature $\mathrm{CD} 4^{+} 8^{-}$ $\mathrm{HSA}^{+}$thymocytes requires the BH3-only protein Bim but is independent of death receptor signaling. Proc Natl Acad Sci 101: 7052-7057.

Viret C, Lamare C, Guiraud M, Fazilleau N, Bour A, Malissen B, Carrier A, Guerder S. 2011. Thymus-specific serine protease contributes to the diversification of the functional endogenous CD4 T cell receptor repertoire. J Exp Med 208: 3-11.
Wang F, Huang CY, Kanagawa O. 1998. Rapid deletion of rearranged $\mathrm{T}$ cell antigen receptor (TCR) V $\alpha$-J $\alpha$ segment by secondary rearrangement in the thymus: Role of continuous rearrangement of TCR $\alpha$ chain gene and positive selection in the $\mathrm{T}$ cell repertoire formation. Proc Natl Acad Sci 95: 11834-11839.

Waterhouse P, Penninger JM, Timms E, Wakeham A, Shahinian A, Lee KP, Thompson CB, Griesser H, Mak TW. 1995. Lymphoproliferative disorders with early lethality in mice deficient in Ctla-4. Science 270: 985-988.

Weih F, Carrasco D, Durham SK, Barton DS, Rizzo CA, Ryseck RP, Lira SA, Bravo R. 1995. Multiorgan inflammation and hematopoietic abnormalities in mice with a targeted disruption of RelB, a member of the NF- $\mathrm{kB} /$ Rel family. Cell 80: 331-340.

Woronicz JD, Calnan B, Ngo V, Winoto A. 1994. Requirement for the orphan steroid receptor Nur77 in apoptosis of T-cell hybridomas. Nature 367: 277-281.

Wu L, Shortman K. 2005. Heterogeneity of thymic dendritic cells. Semin Immunol 17: 304-312.

Yano M, Kuroda N, Han H, Meguro-Horike M, Nishikawa Y, Kiyonari H, Maemura K, Yanagawa Y, Obata K, Takahashi S, et al. 2008. Aire controls the differentiation program of thymic epithelial cells in the medulla for the establishment of self-tolerance. J Exp Med 205: 2827-2838.

Zhu M, Chin RK, Christiansen PA, Lo JC, Liu X, Ware C, Siebenlist U, Fu YX. 2006. NF-кB2 is required for the establishment of central tolerance through an Aire-dependent pathway. J Clin Invest 116: 2964-2971. 


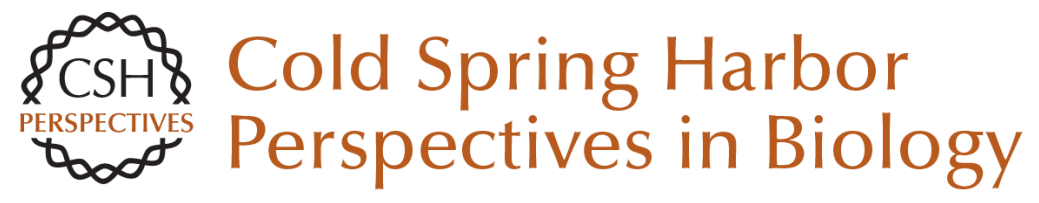

\section{T-Cell Tolerance: Central and Peripheral}

Yan Xing and Kristin A. Hogquist

Cold Spring Harb Perspect Biol 2012; doi: 10.1101/cshperspect.a006957

Subject Collection Immune Tolerance

Regulatory T Cells and Immune Tolerance in the Intestine

Oliver J. Harrison and Fiona M. Powrie

Dendritic Cells: Arbiters of Immunity and

Immunological Tolerance

Kanako L. Lewis and Boris Reizis

Current and Future Immunomodulation Strategies

to Restore Tolerance in Autoimmune Diseases Jeffrey A. Bluestone and Hélène Bour-Jordan

T-Cell Tolerance: Central and Peripheral Yan Xing and Kristin A. Hogquist

Central B-Cell Tolerance: Where Selection Begins Roberta Pelanda and Raul M. Torres

The Immunogenetic Architecture of Autoimmune Disease

An Goris and Adrian Liston
Regulatory T Cells and Immune Tolerance in the Intestine

Oliver J. Harrison and Fiona M. Powrie

Microbiota and Autoimmunity

Alexander V. Chervonsky

Treg Cells, Life History, and Diversity Christophe Benoist and Diane Mathis

Infectious (Non)tolerance--Frustrated

Commensalism Gone Awry? Jesse C. Nussbaum and Richard M. Locksley

Historical Overview of Immunological Tolerance Ronald H. Schwartz

Natural Killer Cell Tolerance: Control by Self or

Self-Control?

Baptiste N. Jaeger and Eric Vivier

For additional articles in this collection, see http://cshperspectives.cshlp.org/cgi/collection/

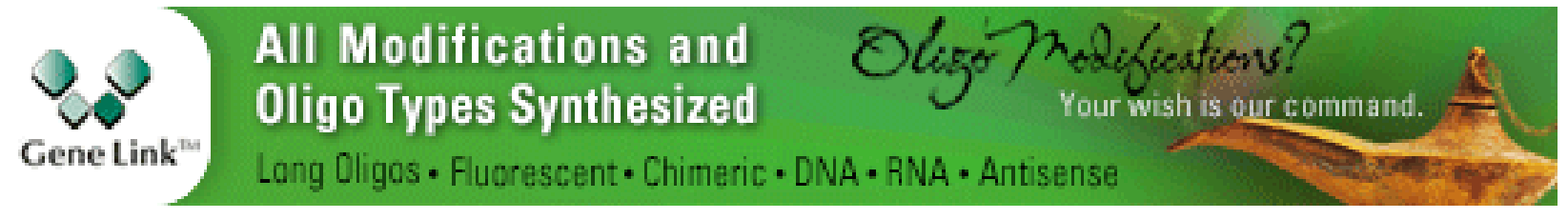

Copyright @ 2012 Cold Spring Harbor Laboratory Press; all rights reserved 